\title{
Healthcare workers' awareness of risks related to the use of $X$-rays in medical procedures
}

\section{Świadomość pracowników ochrony zdrowia na temat zagrożeń związanych z procedurami medycznymi wykorzystującymi promieniowanie RTG}

\author{
Weronika Osmala-Kurpiewska ${ }^{\mathrm{A}-\mathrm{D}, \mathrm{F}}$, Małgorzata Ćwieląg-Drabek ${ }^{\mathrm{CD}, \mathrm{F}}$, Agata Piekut ${ }^{\mathrm{E}, \mathrm{F}}$ \\ Chair of Environmental Health, School of Public Health in Bytom, Medical University of Silesia in Katowice, Bytom, Poland \\ A - research concept and design; $B$ - collection and/or assembly of data; $C$ - data analysis and interpretation; \\ $D$ - writing the article; $E$ - critical revision of the article; $F$ - final approval of the article
}

Address for correspondence

Weronika Osmala-Kurpiewska

E-mail:wosmala@sum.edu.pl

Funding sources

None declared

Conflict of interest

None declared

Received on June 3, 2019

Reviewed on November 7, 2019

Accepted on February 10, 2020

\begin{abstract}
Background. Medical procedures using X-rays are extensively used in current medicine. Despite the many advantages of medical procedures utilizing ionizing radiation, the safety of their application is of great importance.

Objectives. The aim of the study was to examine healthcare professionals' awareness of the risks and safety issues related to medical procedures using $X$-rays.

Material and methods. The research group consisted of 156 healthcare workers employed in 2 medical facilities. A questionnaire devised by one of the authors was used in the study to assess the respondents' awareness of risks related to medical procedures using $X$-rays.

Results. Only half of the respondents knew the rules of radiological protection that a healthcare worker should follow. The majority of the respondents know the types of ionizing radiation shields and are aware of the need for their use. The respondents showed a low level of awareness regarding the dose size of ionizing radiation to which they are exposed during medical imaging and the health effects related to long-term exposure.
\end{abstract}

Conclusions. Educational programs targeting all healthcare professionals are recommended to increase their knowledge of the risks and health consequences related to exposure to ionizing radiation.

Key words: healthcare workers, X-rays, ionizing radiation, medical procedures, imaging diagnostics

Cite as

Osmala-Kurpiewska W, Ćwieląg-Drabek M, Piekut A.

Healthcare workers' awareness of risks

related to the use of $X$-rays in medical procedures.

Piel Zdr Publ. 2020;10(2):83-88. doi:10.17219/pzp/118083

DOI

10.17219/pzp/118083

Copyright

(c) 2020 by Wroclaw Medical University

This is an article distributed under the terms of the

Creative Commons Attribution 3.0 Unported License

(https://creativecommons.org/licenses/by/3.0/) 


\section{Streszczenie}

Wprowadzenie. Procedury medyczne wykorzystujące promieniowanie rentgenowskie (RTG) stanowią grupę badań licznie wykorzystywanych w dobie dzisiejszej medycyny. Mimo wielu zalet płynących z procedur medycznych wykorzystujących promieniowanie jonizujące niebagatelne znaczenie ma bezpieczeństwo ich stosowania.

Cel pracy. Zbadanie świadomości pracowników ochrony zdrowia na temat procedur medycznych z wykorzystaniem promieniowania RTG. W pracy założono, że pracownicy ochrony zdrowia jako grupa badana powinni wykazywać się szczególną świadomością w zakresie ochrony radiologicznej, w tym wpływu promieniowania jonizującego na organizm ludzki.

Materiał i metody. Grupę badaną stanowiło 156 pracowników ochrony zdrowia zatrudnionych w 2 placówkach medycznych. W pracy zastosowano autorski kwestionariusz ankiety. W celu oceny świadomości pracowników ochrony zdrowia na temat procedur medycznych z wykorzystaniem promieniowania RTG przeprowadzono test wiedzy ankietowanych.

Wyniki. Badania wykazały, że tylko połowa ankietowanych zna zasady ochrony radiologicznej, których powinien przestrzegać pracownik ochrony zdrowia. Respondenci w większości znają rodzaje osłon przed promieniowaniem jonizującym oraz są świadomi konieczności ich stosowania. Ankietowani wykazali się niską świadomością w kwestii wielkości dawek promieniowania jonizującego, na które są narażeni w zależności od wykonywanych badań obrazowych, oraz skutków zdrowotnych związanych z długotrwałą ekspozycja.

Wnioski. Wskazane jest opracowanie programów edukacyjnych skierowanych do wszystkich pracowników ochrony zdrowia w celu zwiększenia wiedzy na temat zagrożeń i następstw zdrowotnych związanych z narażeniem na promieniowanie jonizujące.

Słowa kluczowe: pracownicy ochrony zdrowia, promieniowanie jonizujące, diagnostyka obrazowa, procedury medyczne, promieniowanie rentgenowskie

\section{Background}

Medical procedures involving X-ray imaging are extensively used in current medicine. The discovery of $\mathrm{X}$-rays enabled rapid detection of diseases, as well as their prevention and treatment. Despite many advantages of medical procedures using ionizing radiation, the safety of their application is of great importance.

Raising healthcare professionals' awareness of safety issues related to medical procedures using X-rays should be of interest not only to the employees themselves, but also to the managers of healthcare facilities. Ionizing radiation has always been present on Earth, and everyone in the world receives a daily dose of natural radiation throughout life. This radiation consists of isotopes contained in soil, air and water; it is also present in building materials. ${ }^{1}$ The most important source of natural ionizing radiation is radon, which is located under the surface of the Earth and constitutes $41 \%$ of the general occurrence of ionizing radiation. About $74 \%$ of the effective annual radiation dose comes from natural sources, while cosmic radiation contributes only about $8.5 \%$. Artificial sources of ionizing radiation are associated with anthropogenic activity, with medical diagnostics and therapeutic procedures constituting $25 \%$ of the annual total effective dose. ${ }^{2}$

The most frequently used devices emitting ionizing radiation are $\mathrm{X}$-ray machines, computed tomography (CT) devices, dental apparatus, mammographs, and treatment equipment emitting radioactive isotopes. ${ }^{3} \mathrm{Bi}$ ological effects that occur in living organisms as a result of irradiation depend primarily on the energy deposited and the number of cells involved. The energy deposited is determined by the absorbed dose expressed in grays (Gy). When the total destruction of atoms is spread over a larger number of cells, the chances of cell regeneration increase. Sometimes the changes are so inconsiderable that they do not significantly affect the functioning of the cells. ${ }^{4,5}$

Radiation hormesis is a hypothesis based on the statement that low doses of radiation (ranging from $5 \mathrm{mSv}$ to about $100-200 \mathrm{mSv}$ for $\mathrm{X}$ and gamma radiation) can have a positive effect on health. According to this hypothesis, low doses of radiation can stimulate the process of cellular DNA repair, the scavenging of free radicals or the immune system.

Despite many studies on the effects of ionizing radiation on the human body, working in vicinity of its source is associated with risks of harmful effects. Therefore, a linear hypothesis applies in radiological protection, which was adopted in 1959 by the International Commission on Radiological Protection (ICRP). The linear hypothesis assumes that the same radiation effects (genetic mutations or cancers) occur after exposure to both high and low doses. ${ }^{6}$

It should be noted that the linear hypothesis is questionable because there is no convincing data from epidemiological studies or radiobiology research that would demonstrate the existence of carcinogenic effect of doses below $200 \mathrm{mSv}{ }^{7}$ Many factors influence the effects of ionizing radiation, including the immune system and its efficiency. The nature and seriousness of early effects also depend upon whether the exposure is to the whole body or to a part of it. Even though 3-5 Gy of 
whole-body irradiation may kill 50\% of the individuals exposed, the same dose administered to a part of the body will cause only local effects. ${ }^{4}$ The consequences of $\mathrm{X}$-ray irradiation are categorized as deterministic and stochastic effects. When ionizing radiation causes significant disturbances in the function of the cell or cell death, the effects are deterministic: They can lead to a change in the functioning of individual body organs. These effects are observed after exceeding a certain radiation dose threshold. Deterministic effects are various early effects observed soon after irradiation. Changes in the numbers of red and white blood cells, along with skin burns or cataracts, are the most characteristic clinical picture of deterministic effects. ${ }^{9}$ Early radiation response occurs on average up to 90 days after irradiation. The changes that may occur are not permanent, which is why they are usually not dangerous.

Stochastic effects have a certain probability that is directly proportional to the dose. They are various late effects, occurring 90 days or more after irradiation. ${ }^{5}$ Therefore, it can be very difficult to determine whether stochastic effects contributed to the development of diseases such as tumors and hereditary disorders. ${ }^{8}$ Stochastic effects are also responsible for changes in reproductive cells that may contribute to generating mutations in offspring. ${ }^{5}$

The effects of ionizing radiation on the entire organism depend on the radioactivity of the tissues and the area that has been irradiated. The entire human body can be irradiated as a result of a radiation accident or an atomic explosion; the radiation response is then dependent on the absorbed dose. This condition can manifest itself mostly in diarrhea, vomiting and hair loss. As the dose increases, when the whole organism is irradiated, the survival time is reduced. If the dose range is above $100 \mathrm{~Gy}$, this time is reduced to several hours or even minutes.

Doses from 2 to 10 Gy lead to survival times from several days to several weeks. The absorption of doses in this range results in damage to the hematopoietic system and hence to a decrease in the number of morphological elements in the blood. ${ }^{9}$ In this situation, a detailed blood smear shows a reduced number of platelets and erythrocytes. In addition to biochemical changes, vomiting and nausea appear. During the development of radiation sickness, intestinal symptoms such as bloody diarrhea or tissue hemorrhages intensify. Water management is disrupted. As the immunity of the body decreases, secondary infections invade the organism. Doses above 10 Gy contribute to the formation of intestinal syndromes, which are characterized by reduced appetite, diarrhea, dehydration, drowsiness, and fever. A significantly reduced number of white blood cells is observed. All these symptoms cause death within a few days. Doses above 50 Gy contribute to the development of a cerebrovascular syndrome that manifests in a se- ries of disorders: coordination of movements and balance, apathy and agitation, tetanic spasm, diarrhea, seizures, and coma after a few hours. ${ }^{9-11}$ The late effects of ionizing radiation include both tissues, organs and the entire organism. Irradiation of the gonads with a dose of around 4-6 Gy can cause permanent infertility. ${ }^{9}$ For women, a dose of around 3 Gy can cause early menopause. ${ }^{9}$ The main late effects of irradiation include a shortened lifespan, but also the emergence of secondary tumors. Ionizing radiation is carcinogenic, which can be explained by the formation of point mutations or chromosomal translocations creating changes in genetic material. Therefore, medical personnel's awareness regarding the risks of medical procedures using X-rays is crucial to reducing the exposure of both themselves and their patients, because the doses received can be highly variable. ${ }^{8}$

Observation of post-radiation complications resulting from a lack of knowledge on the part of medical personnel led to the adoption of legal regulations defining acceptable doses that patients and medical staff can receive during exposure to ionizing radiation. The most important method is the ALARA (As Low As Reasonably Achievable) principle. ${ }^{8}$

\section{Material and methods}

The study group consisted of 156 healthcare workers (127 women and 29 men) employed in 2 medical facilities: Hospital A (96 respondents) and Hospital B (60 respondents).

The healthcare workers surveyed included doctors, nurses, midwives, paramedics, radiographers, laboratory diagnosticians, medical carers, and sterilization technicians. The author's questionnaire was distributed and collected from January to April 2018. It consisted of personal information (questions about gender, age, education, job position, and place of residence) and 21 single-choice closed questions, including 2 questions about the respondents' subjective assessment of contact with ionizing radiation (Fig. 2), which were not included in the questions verifying the respondents' knowledge, and 19 questions checking their substantive assessment of the ionizing range of various medical applications.

This publication discusses 3 questions from the knowledge test and the 2 subjective assessments presented in Fig. 1 and 3, which the authors consider the most important.

The results obtained were correlated with the respondents' gender, age, level of education, and profession. The results of the questionnaire were developed and analyzed using Microsoft Excel v. 16 spreadsheets (Microsoft Inc., Redmond, USA) and STATISTICA v. 13 (StatSoft Inc., Tulsa, USA), and are presented in Table 1 and Fig. 1-3. 
Table 1. The relationship between gender, age, education and profession, and points obtained in the knowledge test (Spearman's $R$ )

Tabela 1. Zależność pomiędzy płcią, wiekiem, wykształceniem oraz wykonywaną pracą a punktami uzyskanymi w teście wiedzy (korelacja $R$ Spearmana)

\begin{tabular}{|c|c|c|c|c|}
\hline Variable & $\begin{array}{l}\text { Valid } \\
N\end{array}$ & Spearman's $R$ & $t(N-2)$ & $p$-value \\
\hline $\begin{array}{l}\text { Gender } \\
\text { - total points }\end{array}$ & 156 & 0.0266882 & 0.331310 & 0.74086 \\
\hline $\begin{array}{l}\text { Age } \\
\text { - total points }\end{array}$ & 156 & 0.0600733 & 0.746838 & 0.45630 \\
\hline $\begin{array}{l}\text { Education } \\
\text { - total points }\end{array}$ & 156 & -0.1566142 & -1.967815 & 0.05089 \\
\hline $\begin{array}{l}\text { Profession } \\
\text { - total points }\end{array}$ & 156 & -0.1127193 & -1.407781 & 0.16121 \\
\hline
\end{tabular}

Fig. 1. Answers of the respondents to the question "Which of the following principles of radiological protection do you think should be followed by healthcare professionals?"

Ryc. 1. Odpowiedzi ankietowanych osób na pytanie: „Których z wymienionych zasad ochrony radiologicznej Pana/Pani zdaniem powinni przestrzegać pracownicy ochrony zdrowia?"

Fig. 2. Answers of the respondents to the question "Are you afraid of examinations using ionizing radiation?"

Ryc. 2. Odpowiedzi respondentów na pytanie "Czy obawia się Pan/ Pani badań wykorzystujących promieniowanie jonizujące?"

Fig. 3. Answers of the respondents to the question "In which period of pregnancy do you think irradiation can cause numerous malformations and even death of offspring?"

Ryc. 3. Odpowiedzi pracowników ochrony zdrowia na pytanie „W którym okresie trwania ciąży Pana/ Pani zdaniem napromieniowanie może spowodować liczne wady rozwojowe, a nawet śmierć potomstwa?"

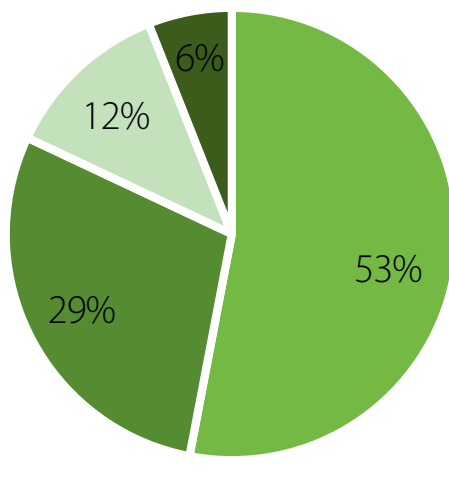

- all rules listed

- the exposure time should be as short as possible

" the distance between the operator and the radiation source should be as great as possible

- there should be shields between the operator and the source
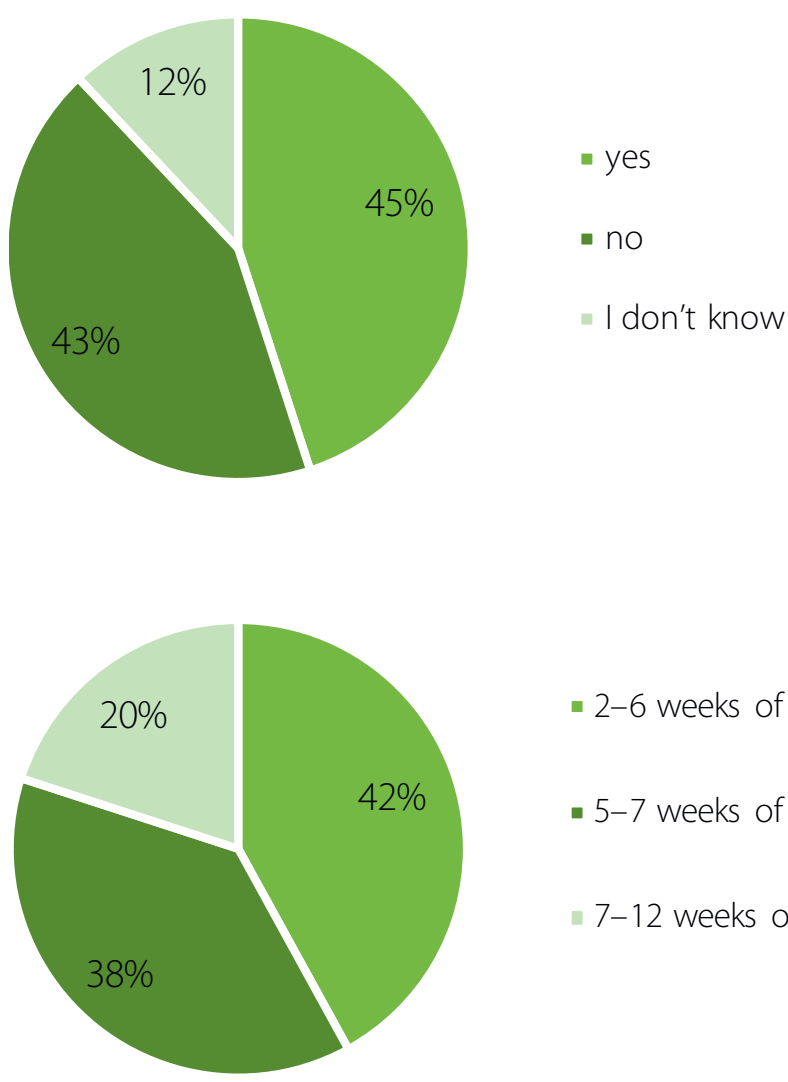

- 2-6 weeks of pregnancy

- 5-7 weeks of pregnancy

- 7-12 weeks of pregnancy 


\section{Results}

In the test of knowledge regarding medical procedures with the use of X-rays, the respondents scored from 3 ( $5 \%$ of respondents) to 15 ( $2 \%$ of respondents) out of a possible 19 points. The most common score (16\%) was 9 points.

Correlations were considered significant at $p<0.05$. The linear regression analysis and Pearson's linear correlation coefficient for the test of knowledge did not show a linear relationship with respect to sex, age, education, or job position (Table 1). The results of the study showed that education does not significantly affect the level of knowledge of medical procedures using X-rays; this may be related to the fact that the education of the respondents was only slightly differentiated: $94 \%$ of respondents had secondary (46\%) or higher education (48\%).

The healthcare workers' knowledge of the first type of damage that may occur after absorbing low doses of ionizing radiation varied widely. Almost half of the respondents (48\%) answered that it is intestinal damage; $26 \%$ that it is the brain damage; while $26 \%$ gave the correct answer, indicating that the hematopoietic system is the most affected.

A question related to the type of examination characterized by the largest range of X-ray doses also caused difficulties for the respondents. Only about $1 / 5$ of the healthcare workers $(22 \%)$ gave the correct answer that it is CT. The remaining $78 \%$ of the respondents chose incorrect answers, indicating X-ray diagnostics (58\%) and mammography (20\%). Over half of the respondents (53\%) knew the correct answer to a question about the principles of radiological protection that healthcare professionals should follow, indicating "all of the rules listed" (47\%).

\section{Discussion}

Research conducted among healthcare workers (including nurses, midwives, paramedics, and laboratory diagnosticians) showed that their level of knowledge about the risks associated with medical procedures using ionizing radiation is insufficient.

One question in the survey that proved quite difficult to answer was "In which period of pregnancy do you think irradiation can cause numerous malformations or even the death of the offspring?" Pregnancy is a special period, so X-ray examinations should only be performed if they are necessary to protect the mother's life and health. The effects of irradiation during pregnancy depend on the duration and dose of radiation. Irradiation of a fertilized egg before it is implanted in the endometrium may lead to the death of a zygote or embryo. Studies conducted in mice consisting in irradiation of a fertilized mouse egg with a 2 Gy dose in the early preimplantation period caused it to die in up to $80 \%$ of cases. On the $5^{\text {th }}$ day after fertilization this percentage is halved. The correct answer to the question is that it is the period between $2^{\text {nd }}$ and $6^{\text {th }}$ week of pregnancy, when organogenesis occurs (the process of organ formation and development). During this period, irradiation can cause numerous malformations that can lead to perinatal death. ${ }^{9}$ Interestingly, in the regulation of Polish Council of Ministers dated January 18, 2005, on limiting exposure to ionizing radiation, women are not prohibited from work exposing them to ionizing radiation while pregnant as long as the woman and unborn child are not exposed to an effective dose exceeding $1 \mathrm{mSv}$; this stipulation is effective from the moment the female employee notifies the head of the organizational unit about pregnancy. ${ }^{10}$ In a study by Selmi and Natarajan concerning the knowledge of young doctors about exposure to ionizing radiation, a very limited awareness of the group examined on the subject of doses and health risks was indicated. ${ }^{12}$ A study carried out in Spain by Lumbreras et al. showed that almost $80 \%$ of the doctors surveyed had never heard of European recommendations regarding doses of ionizing radiation. ${ }^{13}$ A low level of awareness among physicians regarding the effects of radiation on patients, including pregnant women, was also demonstrated by an Indian study conducted by Suresh et al. ${ }^{14}$ A Turkish study by Yurt et al. showed that general knowledge about radiation, radiation protection, health risks, and doses used in radiological procedures is insufficient among medical professions using ionizing radiation in their work. ${ }^{15}$ Faggioni et al. obtained similar results by interviewing a group of 159 young doctors and medical students in Italy. ${ }^{16}$

The respondents also showed a lack of knowledge regarding the types of examinations that are characterized by the broadest range of X-ray doses. Research carried out by Domienik and Zmyślony indicates that there are significant differences in the doses used during CT and classic X-ray diagnostics. ${ }^{17}$ The differences are due to the CT technique itself. During a single CT scan, several X-rays are performed around the axis of rotation of the X-ray lamp, parallel to the long axis of the patient.

A good example for comparing these 2 techniques is a comparison of a standard chest X-ray in posterioranterior (PA) projection with a chest examination using CT. One standard X-ray image involves a dose many times smaller than in the case of the CT scan. Healthcare professionals' lack of knowledge in this area may be due to the fact that CT has been introduced relatively recently, in the early 1990s. The impression that CT is a more modern and detailed technique means that it is more and more often chosen by doctors. A study conducted in Sudan on 250 representatives of medical professions (radiographers, doctors, dentists, laboratory diagnosticians, and nurses) aimed at studying their 
knowledge of the impact of ionizing radiation on growing environmental threats. ${ }^{18}$ The study showed that radiographers with bachelor education had the highest levels of knowledge in this field. It was determined that $75 \%$ of medical staff gained knowledge in this field thanks to lectures and seminars, and the remaining 25\% from public information.

The role of compulsory education in the field of radiation protection in medical schools was also emphasized in a study conducted by Arslanoğlu et al. regarding the level of knowledge of doctors and trainees on the doses of ionizing radiation to which patients are exposed during radiological examinations. ${ }^{19}$ These authors emphasized that training medical personnel in the field of exposure to ionizing radiation when they are studying and qualifying to work in the medical profession is important to safety and health of both healthcare workers and patients.

It should be emphasized that healthcare professionals are responsible for their own health as well as their patients' health. Unfortunately, despite the progress and rapid development of diagnostic techniques and their increasing use, the problem of health risks resulting from exposure to X-rays is still downplayed, which is clear from the limited number of publications and scientific papers on this issue in Poland.

\section{Conclusions}

The study shows that only half of the respondents know the rules of radiological protection a healthcare worker should obey. The awareness of the respondents regarding the doses of ionizing radiation to which they are exposed during imaging examinations and the health effects associated with long-term exposure to low doses of ionizing radiation was low. It is advisable to develop educational programs, targeted to all healthcare professionals, in order to increase knowledge about health risks and consequences related to exposure to ionizing radiation.

\section{ORCID iDs}

Weronika Osmala-Kurpiewska (1) https://orcid.org/0000-0002-1076-3998 Małgorzata Ćwieląg-Drabek (1) https://orcid.org/0000-0002-4219-9949 Agata Piekut (1) https://orcid.org/0000-0003-0564-2849

\section{References}

1. Shahbazi-Gahrouei D, Gholami M, Setayandeh S. A review on natural background radiation. Adv Biomed Res. 2013;2:65. doi:10.4103 /2277-9175

2. Dziubanek G, Wojciechowska-Kumięga M, Kateusz K. Health risk related to electromagnetic radiation. In: Marchwińska-Wyrwał E, Dziubanek G, eds. Environmental Health Risk Factors [in Polish]. Katowice, Poland: Medical University of Silesia in Katowice; 2014:125-134.

3. Dance DR, Christofides S, Maidment ADA, McLean ID, Ng KH. Diagnostic Radiology Physics: A Handbook for Teachers and Students. Vienna, Austria: IAEA; 2014.

4. Aggarwal L. Biological effects of ionizing radiation. Shodh Prerak. 2014;4(1):342-348.

5. Choudhary S. Deterministic and stochastic effects of radiation. Canc Therapy \& Oncol Int J. 2018;12(2):1-2. doi:10.19080 /CTOIJ.2018.12.55583

6. Zdrojewicz Z, Szlagor A, Wielogórska M, Nowakowska D, Nowakowski J. The influence of ionizing radiation on the human body [in Polish]. Family Medicine \& Primary Care Review. 2016;18(2): 174-179. doi:10.5114/fmpcr/43945

7. Strzelczyk J, Potter W, Zdrojewicz Z. Rad-by-rad (bit-by-bit): Triumph of evidence over activities fostering fear of radiogenic cancers at low doses. Dose Response. 2007;5(4):275-283. doi:10.2203 /dose-response.07-021.Strzelczyk

8. Kim DI. Preface: How dangerous are X-ray studies that we undertake every day? J Korean Med Sci. 2016;31(1):S2-S3. doi:10.3346 /jkms.2016.31.S1.S2

9. Pruszyński B, Cieszanowski A. Radiology. X-ray Imaging, CT, and Ultrasound [in Polish]. $3^{\text {rd }}$ ed. Warsaw, Poland: Wydawnictwo Lekarskie PZWL; 2014.

10. Regulation of the Council of Ministers of 18 January 2005 on the limit doses of ionizing activity. DzU 2005 Nr 20, poz 168.

11. Kadhim M, Salomaa S, Wright $E$, et al. Non-targeted effects of ionising radiation: Implications for low dose risk. Mutat Res. 2013;752(2):84-98. doi:10.1016/j.mrrev.2012.12.001

12. Selmi M, Natarajan MD. Radiation awareness amongst junior doctors. Journal of Advances in Radiology and Medical Imaging. 2016;1(2):1-6. doi:10.15744/2456-5504.1.205

13. Lumbreras B, Vilar J, González-Álvarez I, et al. Evaluation of clinicians' knowledge and treatments regarding medical radiological exposure: Findings from a mixed-methods investigation (survey and qualitative study). BMJ Open. 2016;6(10):e012361. doi:10.1136 /bmjopen-2016-012361

14. Suresh S, Rajagopal KV, Sabu KM. Perception of radiation awareness among medical doctors in India. Int J Pharm Biol Sci. 2013;3(3): 371-376. https://www.ijpbs.com/ijpbsadmin/upload/ijpbs_5267e 57f86f1f.pdf. Accessed on April 2, 2020.

15. Yurt A, Çavuşoğlu B, Günay T. Evaluation of awareness on radiation protection and knowledge about radiological examinations in healthcare professionals who use ionized radiation at work. Mol Imaging Radionucl Ther. 2014;23(2):48-53. doi:10.4274/mirt.00719

16. Faggioni L, Paolicchi F, Bastiani L, Guido D, Caramella D. Awareness of radiation protection and dose levels of imaging procedures among medical students, radiography students, and radiology residents at an academic hospital: Results of a comprehensive survey. Eur J Radiol. 2017;86:135-142. doi:org/10.1016 /j.ejrad.2016.10.033

17. Domienik J, Zmyślony M. Doses to adult patients from computed tomography examinations [in Polish]. Med Pr. 2012;63(6):629-635.

18. Esmeal M, Esmeal A. Knowledge of the effect of ionizing radiation, Khartoum state medical personnel. IOSR Journal of Dental and Medical Sciences. 2013;10(3):59- 64. doi:10.9790/0853-1035964

19. Arslanoğlu A, Bilgin S, Kubalı Z, Ceyhan MN, Illhan MN, Maral I. Doctors' and intern doctors' knowledge about patients' ionizing radiation exposure doses during common radiological examinations. Diagn Interv Radiol. 2007;13(2):53-55. https://www.dirjournal.org /en/doctors-and-intern-doctors-knowledge-about-patientsionizing-radiation-exposure-doses-during-common-radiological -examinations-131036. Accessed on April 2, 2020. 